\title{
De uma freguesia serra acima à costa atlântica: produção e comércio da aguardente na cidade de São Paulo (1765-1822)*
}

\author{
Denise Aparecida Soares de Moura \\ Universidade Estadual Paulista "Júlio de Mesquita Filho" \\ São Paulo, SP, Brasil \\ dmsoa1@yahoo.com.br
}

\section{RESUMO}

Este artigo apresenta conclusōes de uma pesquisa sobre a produção da aguardente em engenhos e sítios de uma freguesia da cidade de Sáo Paulo, dentro do panorama mais amplo do comércio desse produto no Império português entre 1765 e 1822. Para tanto foram utilizados os Maços de População da Capital, especialmente do ano de 1802, e os mapas de importação e exportaçáo da vila de Santos produzidos por sua alfândega para a Real Junta de Comércio, no Rio de Janeiro.

Palavras-chave: aguardente; comércio colonial; senhores de engenho; produtor rural; freguesias.

\begin{abstract}
This article presents the conclusions of a research about the production and trade of liquor (the Brazilian sugarcane alcohol) in rural estates of a parish of the city of São Paulo, within the context of this product's trade in the Portuguese Empire at large between 1765 and 1822. The research was based on the Maços de População da Capital, a population census for the city of Sáo Paulo, especially the 1802 issue, and the import-export maps produced by Customs at the port of the village of Santos for the Real Junta de Comércio [Royal Chamber of Commerce] in Rio de Janeiro.
\end{abstract}

Keywords: Brazilian liquor; colonial trade; sugar mill owners; rural production; colonial parishes.

* Trabalho financiado por auxílios à pesquisa concedidos pela Fapesp e pelo CNPq.

Artigo recebido em 2 de dezembro de 2011 e aceito em 13 de março de 2012. 
A cidade de Sáo Paulo, capital da capitania de mesmo nome, na primeira metade do século XIX possuía freguesias rurais que produziam cana-de-açúcar. Essa produção, contudo, tinha como alvo a fabricação de aguardente, que tanto atendia a demanda do mercado consumidor citadino, como escoava para o litoral, via Caminho do Mar, até a vila de Santos.

$\mathrm{Na}$ costa da capitania de São Paulo essa produção de aguardente era redistribuída no continente, via comércio de cabotagem, ou seguia para Portugal. O produto, portanto, complementava a demanda do mercado externo e integrava freguesias rurais situadas em cidades serra acima e no sertão do Império português do período. Recentemente, um periódico foi dedicado totalmente ao assunto da produção e comércio da aguardente, o que demonstra sua relevância ${ }^{1}$.

Neste texto são apresentadas conclusóes alcançadas em uma pesquisa sobre as unidades produtivas de uma freguesia rural da cidade de São Paulo: a freguesia do Ó. Para tanto, foi utilizada uma documentação digitalizada e parcialmente disponível na internet, no site do Arquivo do Estado de São Paulo $^{2}$, intitulada Maços de População, um tipo de censo que fornece informaçôes mais detalhadas de cada domicílio, especialmente a partir de 1802.

Essa fonte foi escolhida para o levantamento de dados que fundamentam as conclusóes ora apresentadas devido a sua capacidade em fornecer informaçóes que permitem em grande medida conceituar a produção da aguardente, em especial, mas também os agentes produtores destas freguesias rurais.

O governador da capitania de Sáo Paulo, d. Luis Antonio de Sousa Botelho Mourão (1765-1775), implantou o levantamento de dados de sua população como parte de um programa mais amplo da Coroa portuguesa de revitalização do controle da mesma capitania, que desde 1748 estava subordinada ao Rio de Janeiro. Esse levantamento de informaçóes sobre a populaçáo também teve o objetivo de utilizá-la na formação de quadros militares para a manutenção da soberania do Império em toda a parte centro-sul do continente ${ }^{3}$.

Mas foi com Antonio Manuel de Melo Castro e Mendonça (1797-1802) que os registros de população e produção da capitania alcançaram maior rigor. Em seu governo também houve uma preocupação maior em racionalizar e profissionalizar o levantamento de dados ${ }^{4}$. Esse náo teria sido um dos motivos que levaram este governador a sofrer tanta oposição na vila de Santos e na cidade de São Paulo?

O fato é que o pensamento mais burocrático desse governador favoreceu os pesquisadores atuais no sentido de terem uma fonte para o início do século XIX com características bem diferentes de como ela era produzida no século XVIII.

Ou seja, além de nome, idade, estado civil, número de escravos, filhos, agregados, ela passava a contar com definição de ocupaçôes, quantidade e tipo de produçôes, notificação de existência de alguma alteração em dado fogo, como nascimento, morte ou venda de algum escravo, nacionalidade de livres e escravos, chegada de um novo agregado e deslocamentos do registrado dentro de outras partes do Império.

Essa fonte, portanto, viabiliza a formação de um banco de dados com informaçóes sobre a população e a produção das freguesias rurais de São Paulo, que podem nortear a pesquisa segura em conjuntos documentais mais informativos, como os registros paroquiais, que ampliam os recursos empíricos para a conceituação das sociedades coloniais de antigo regime destas freguesias ${ }^{5}$.

\footnotetext{
${ }^{1}$ Cf. International Journal of Entrepreneurship and Small Business, v. 9, issue 4, 2010.

${ }^{2}$ Disponível em: <www.arquivodoestado.sp.gov.br>.

${ }^{3}$ BELLOTTO, Heloísa Liberalli. Autoridade e conflito no Brasil colonial: o governo do Morgado de Mateus em São Paulo (1765-1775). 2. ed. São Paulo: Alameda, 2007.

${ }^{4}$ PETRONE, Maria Theresa Schorer. A lavoura canavieira em São Paulo. Expansão e declínio (1765-1888). São Paulo: Difusão Europeia do Livro, 1968. p. 137-138.

${ }^{5}$ Esta sugestão de pesquisa surgiu inspirada na leitura de instigante artigo: FRAGOSO, João. Efigênia Angola, Francisca Muniz forra parda, seus parceiros e senhores: freguesias rurais do Rio de Janeiro, século XVIII. Uma contribuição metodológica para a história colonial. Topoi, Rio de Janeiro, v. 11, n. 21, p. 74-106, jul./dez. 2010.
} 
Nas atas das vereanças e nos papéis oficiais diversos produzidos pela Câmara da cidade de São Paulo na segunda metade do século XVIII e nos mapas de importação e exportação do porto de Santos, localizados no Arquivo Nacional do Rio de Janeiro, foram levantados dados posteriormente organizados e analisados qualitativa e quantitativamente. Eles que levam à conclusão de que a fabricação da aguardente em freguesias rurais da cidade de Sáo Paulo, como a da Freguesia do Ó, atendia uma demanda pelo produto na parte sul do continente da América portuguesa, estendendo-se até para os domínios hispânicos e para a Europa.

Com isto, as conclusóes desta pesquisa concordam com certa linha investigativa que há tempos vem demonstrando o caráter diversificado dos circuitos mercantis das várias áreas da América portuguesa e a formação de interesses específicos, de acordo com as potencialidades econômico-financeiras de cada região ${ }^{6}$.

Os dados levantados e sistematizados por esta pesquisa indicam que a cidade de São Paulo não foi um mero entreposto da cana produzida nos municípios de Sorocaba, Piracicaba, Mogi Guaçu e Jundiaí, o tradicional quadrilátero do açúcar ${ }^{7}$. A cidade também foi uma área formada por freguesias rurais produtivas, movimentadas pelo pequeno negócio das fábricas de aguardente, integradas a circuitos mercantis mais distantes, na costa da capitania, do continente e marítimo.

Com isto, as conclusóes desta pesquisa combinam ainda com a recente historiografia sobre a cidade e a sociedade de São Paulo, que vem reforçando o caráter dinâmico e diversificado de sua economia e o papel integrador e atuante de seus negociantes na regiáo centro-sudeste-sul do Brasil e no Império português ${ }^{8}$.

A aguardente da cana foi um dos principais componentes formadores do sistema atlântico ${ }^{9}$. Na segunda metade do século XVIII esse produto entrou na pauta das preocupaçóes modernizadoras do Império português. Letrados como João Pereira Manso, naturalista e professor de gramática, foram patrocinados pela Coroa para escrever um método de ensino do transporte da aguardente do Brasil para Portuga ${ }^{10}$. Nas freguesias das cidades e vilas costeiras, serra acima e nos sertôes, lavradores se de-

${ }^{6}$ FRAGOSO, João Luís R. Homens de grossa aventura: acumulação e hierarquia na praça mercantil do Rio de Janeiro (1790-1830). Rio de Janeiro: Civilizaçáo Brasileira 1998; OSÓRIO, Helen. O Império português: no sul da América estancieiros, lavradores e comerciantes. Porto Alegre: Editora da UFRGS, 2007; SAMPAIO, Antonio Carlos Jucá de. Famílias e negócios: a formação da comunidade mercantil carioca na primeira metade do setecentos. In: FRAGOSO, João Luis R. et al. Conquistadores e negociantes: histórias de elites no Antigo Regime nos trópicos. América Lusa, séculos XVI a XVIII. Rio de Janeiro: Civilização Brasileira, 2007. p. 225-266.

${ }^{7}$ PETRONE, Maria Teresa Schorer. A lavoura canavieira em São Paulo, op. cit. p. 41.

${ }^{8}$ HOLANDA, Sérgio Buarque de. Movimentos de população no século XVII. Revista do Instituto de Estudos brasileiros, São Paulo, v. 1, n. 1, p. 54-111, 1969; MONTEIRO, John. Negros da terra: índios e bandeirantes nas origens de São Paulo. São Paulo: Companhia das Letras, 1994; DIAS, Maria Odila Leite da Silva. Quotidiano e poder em São Paulo no século XIX. 2. ed. São Paulo: Brasiliense, 1995; NAZZARI, Muriel. O desaparecimento do dote. Mulheres, famílias e mudança social em São Paulo, 1600-1900. São Paulo: Companhia das Letras, 2001; METCALF, Alida C. Family and frontier in colonial Brazil. Santana de Parnaíba, 1580-1822. Berkeley and Los Angeles, Califórnia: University of California Press, 1992; KUZNESOF, Elizabeth Anne. Household economy and urban development. São Paulo, 1765 a 1836. Berkeley: University of California, 1976; BLAJ, Ilana. A trama das tensóes: o processo de mercantilização de São Paulo colonial (1681-1721). São Paulo: Humanitas; FFLCH/USP; Fapesp, 2002; MARCÍLIO, Maria Luiza. Crescimento demográfico e evolução agrária paulista, 1700-1836. São Paulo: Hucitec; Edusp, 2000; MOURA, Denise A. Soares. Sociedade movediça: economia, cultura e relações sociais em São Paulo. São Paulo: Unesp, 2006; ARAÚJO, Maria Lúcia Viveiros. Os caminhos das riquezas dos paulistanos na primeira metade do Oitocentos. São Paulo: Hucitec; Fapesp, 2006; BORREGO, Maria Aparecida de Menezes. A teia mercantil: negócios e poderes em São Paulo (1711-1765). São Paulo: Alameda, 2010.

${ }^{9}$ ALENCASTRO, Luiz Filipe de. O trato dos viventes: formação do Brasil no Atlântico sul, séculos XVI e XVII. São Paulo: Companhia das Letras, 2000; BAILYN, Bernard. Atlantic history: concept and contours. Cambridge, Massachussetts: Harvard University Press, 2005; RUSSELL-WOOD, A. J. R. Sulcando os mares: um historiador do Império português enfrenta a "Atlantic History". História, Franca, v. 28, n. 1, p 17-70, jul./dez. 2009.

${ }^{10}$ MANSO, João Pereira. Memória sobre o methodo econômico de transportar para Portugal a aguardente do Brazil com grande proveito dos fabricantes e comerciantes. Lisboa: Na officina de Thadeo Simão Ferreira, 1768. 
dicavam à sua produção. $\mathrm{O}$ caráter estratégico desse produto no tráfico de escravos na costa da América portuguesa até os portos platinos de Montevidéu e Buenos Aires vem sendo estudado ${ }^{11}$.

A aguardente de cana foi também uma moeda de troca local e transatlântica em partes do Império português e hispânico, em especial no comércio negreiro com regiōes da África. Na América portuguesa, o Rio de Janeiro, que controlava o tráfico de escravos angolano, foi um dos mais importantes produtores e distribuidores de jeribita ou aguardente. O produto era consumido nas tabernas e usado para pagamento de tropas e milícia ${ }^{12}$.

Apesar da importância da aguardente na formação da civilizaçáo do Atlântico, no Brasil, o foco das pesquisas ainda recai sobre a indústria da cana-de-açúcar. A aguardente, um derivado desse produto com valor de venda inferior, recebe o tratamento de um subproduto muitas vezes apenas mencionado na historiografia ${ }^{13}$.

A investigação histórica sobre a produção e o comércio da aguardente num período longo, como o que se estende de 1765 a 1822, esbarra em dificuldades impostas pela ausência de estudos específicos. Há também algumas limitaçôes impostas pelas fontes primárias, como a irregularidade na quantificação da produção e circulação desse produto no mercado interno e nas exportações.

Certamente que os números não oferecem um quadro preciso, mas são indicadores interessantes para a formulaçáo de hipóteses e conclusóes ${ }^{14}$.

\section{Um produto entre demandas de mercado}

Nos Impérios ibéricos, as cidades coloniais, que funcionaram como capitais de capitania ou província, também foram áreas produtivas. A cidade de São Paulo, situada no centro-sul da América portuguesa, tinha essa condição, que muito faz lembrar a região bonarense ${ }^{15}$.

São Paulo surgiu como um colégio implantado pelos jesuítas em 1554 numa área que distava algumas léguas do litoral. Uma íngreme serra, chamada Serra do Mar, separava a cidade da costa. Em 1560, o agrupamento em torno do colégio foi elevado a vila, através da instalação da Câmara Municipal.

Geograficamente, a vila, elevada a cidade apenas em 1711, estava a meio caminho entre o litoral e o interior, o que lhe proporcionou a condição de ponto nevrálgico para as expediçóes e comunicaçóes com o interior centro-sul da América prtuguesa.

De fato, algumas cidades coloniais tiveram essa condição de porta de entrada para os sertóes e isso deve ser devidamente levado em consideração ao se refletir sobre sua posição na política dos impérios, sobre suas atividades econômicas e sobre os segmentos sociais que viviam em seu sítio. Casos semelhantes existiram também na Nova Espanha ${ }^{16}$.

\footnotetext{
${ }^{11}$ BORUCKI, Alex. The slave trade to the Río de la Plata. Trans-imperial networks and Atlantic warfare, $1777-1812$. Colonial Latin American Review, v. 20, n. 1, March 2011.

${ }^{12}$ PRADO JR., Caio. Formação do Brasil contemporâneo. São Paulo: Martins, 1942. p. 142; FERREIRA, Roquinaldo. Dinâmica do comércio intracolonial: geribitas, panos asiáticos e guerra no tráfico angolano de escravos (século XVIII). In: FRAGOSO, João et al. (Org). O antigo regime nos trópicos: a dinâmica imperial portuguesa. Rio de Janeiro: Civilização Brasileira, 2001. p. 339-378; MOORE, Javier Leandro Maffucci. Indios, inmigrantes y criollos en el nordeste Santafesino (1860-1890). Un caso de violencia en una sociedad de frontera. Revista Andes, Salta, v. 18, p. 11, 2007.

${ }^{13}$ PETRONE, Maria Thereza Schorer, A lavoura canavieira em São Paulo, op. cit.; SCHWARTZ, Stuart B. Segredos internos: engenhos e escravos na sociedade colonial. São Paulo: Companhia das Letras, 1998; FERLINI, Vera. Terra, trabalho e poder: o mundo dos engenhos no Nordeste colonial. Bauru: Edusc, 2003.

${ }^{14}$ MOURA FILHO, Heitor Pinto de. O uso da informaçáo quantitativa em história - tópicos para discussão. Locus: Revista de História, Juiz de Fora, v. 14, n. 1, p. 41-90, 2008.

${ }^{15}$ GARAVAGLIA, Juan Carlos. Pastores y labradores de Buenos Aires: una historia agraria de la campańa bonaerense 17001830. Buenos Aires: Ediciones de la Flor, 1999.

${ }^{16}$ CHÁVEZ, Claudia Paulina Machuca. Cabildo, negociación y vino de cocos: el caso de la Villa de Colima en el siglo XVII. Anuario de Estudios Americanos, Sevilla, v. 66, n. 1, p. 173-192, 2009.
} 
Como a maioria das capitais de capitanias, a cidade de Sáo Paulo tinha uma baixa densidade populacional, mas acompanhava o crescimento demográfico vivido por todo o centro-sul, especialmente a partir da transferência da família real para a cidade do Rio de Janeiro em 1808.

Em 1822, metade das capitais de capitania tinha por volta de 10 mil habitantes. Em 1776, a cidade possuía 3.820 habitantes. Em 1794, esse número saltou para 9.359 e, em 1815, para cerca de 25.313. As duas únicas maiores cidades em termos populacionais, Rio de Janeiro e Bahia, reuniam, respectivamente, 100 mil e 60 mil habitantes ${ }^{17}$.

Como uma cidade da América portuguesa, São Paulo, entre 1765 e 1822, esteve sob o impacto de pelo menos três conjunturas específicas: a de um tipo de "neomercantilismo" promovido pelo ministério do marquês de Pombal e sob o reinado de d. José I, entre 1750 e 1777. A fase seguinte, dominada pelas secretarias de Estado de d. Martinho de Melo e Castro (1778-95) e de d. Rodrigo de Souza Coutinho (1796-1801). O período iniciado em 1807 e concluído em 1822, com a independência, que marcou o colapso do vínculo colonial entre Portugal e domínios do Brasi ${ }^{18}$.

Cada um desses momentos foi caracterizado por políticas econômicas com tendências próprias, mas que não se interromperam abruptamente com o fim de cada secretariado de Estado ou período. Especialmente Martinho de Melo e Castro tentou prosseguir com as propostas pombalinas ${ }^{19}$.

Contudo, a política econômica formulada pela Coroa portuguesa para o Brasil entre 1750 e 1822 esbarrou em problemas maiores, como as transformaçóes e as novas demandas do mercado europeu, o avanço do liberalismo e as próprias respostas dadas pelos interesses de produtores e comerciantes às novas exigências do mercado internacional e interno.

A política pombalina, levada a cabo no Brasil pelo marquês de Lavradio, pode ser considerada uma consistente e importante fase de modernização da economia da América portuguesa. Especialmente no final desse ministério, a produção de produtos não tradicionais, como trigo, arroz, índigo, cânhamo e fibras em geral, ganhou fôlego ${ }^{20}$.

Na capitania de Sáo Paulo, esse mesmo período contou com a atuação do Morgado de Mateus, d. Luis de Souza Botelho Mourão (1765-75), que estimulou a diversificação da produção e o comércio externo da capitania. Tal atuação levou-o também a se preocupar com a melhoria da descida da serra do Mar, via terrestre obrigatória que ligava a capitania ao exterior. Contudo, suas preocupaçóes só seriam concretizadas no governo de Bernardo José de Lorena (1788-97), que pavimentou o caminho.

As visões e ações do marquês de Lavradio e do Morgado de Mateus em São Paulo, contudo, foram bastante limitadas pelos "pressupostos neomercantilistas pombalinos" ${ }^{21}$ e por isso esbarraram nos interesses próprios de produtores e negociantes das regiôes específicas do interior ou litoral da América portuguesa.

\footnotetext{
${ }^{17}$ Todos os dados levantados em ALDEN, Dauril. O período final do Brasil colônia, 1750-1808. In: BETHELL, Leslie (Org.). História da América Latina Colonial. São Paulo: Edusp; Brasília: Fundação Alexandre de Gusmão, 1999. v. 2, p. 695; QUEIROZ, Suely Robles Reis de. São Paulo. Madri: Editorial Mapfre, 1992.

${ }^{18}$ DISNEY, A. R. A history of Portugal and the Portuguese Empire. Nova York: Cambridge University Press, 2009. p. $277-$ 285.

${ }^{19}$ Ibidem, p. 279. Para uma conceituação cuidadosa de cada uma dessas conjunturas interessa ler as seguintes pesquisas: MATTOS, Renato de. Política, administração e negócios na capitania de São Paulo e sua inserção nas relaçóes mercantis do Império português (1788-1808). Dissertação (Mestrado em História Social) — Programa de Pós-Graduação em História Social, Universidade de São Paulo, São Paulo, 2009; MEDICI, Ana Paula. Administrando conflitos: o exercício do poder e os interesses mercantis na capitania/província de São Paulo (1765-1822). Tese (Doutorado em História Social) — Programa de Pós-Graduação em História Social, Universidade de São Paulo, São Paulo, 2010.

${ }^{20}$ ALDEN, Dauril. Royal government in colonial Brazil: with special reference to the administration of the marquis of Lavradio, Viceroy, 1769-1779. Berkeley; Los Angeles: University of California Press, 1968.

${ }^{21}$ DISNEY, A history of Portugal and the Portuguese Empire, op. cit. p. 279.
} 
O Morgado de Mateus, por exemplo, chegou a enfrentar resistências de produtores e negociantes locais à sua tentativa de dirigir a economia da capitania de São Paulo para o Atlântico. Em 1768 esse governador propôs e até conseguiu adeptos para a formaçáo de uma companhia de comércio direto da capitania com o Reino. Porém, não só enfrentou a oposição da burocracia municipal, que defendeu a prioridade do mercado consumidor local, como a oposição dos negociantes da vila de Santos, principal porto da capitania capacitado para a navegação marítima, em abrir mão do comércio costeiro ${ }^{22}$.

De 1770 em diante as doutrinas de livre mercado tenderam a ganhar força na Europa, com ressonâncias no Brasil. O mercado europeu diversificou suas demandas e o território da América portuguesa oferecia potencial tanto produtivo como comercial para novos produtos. Essa realidade, inevitavelmente, estimulou o aumento do contrabando ${ }^{23}$.

A aguardente, um dos derivados de um produto tradicional da pauta de exportaçóes do Brasil, como o açúcar, foi uma dessas novas demandas do mercado do continente americano e da Europa. O interesse pelo produto era tanto colonial como metropolitano.

$\mathrm{Na}$ América do Norte, por exemplo, em partes como Maryland, Nova York, Nova Inglaterra, Nova Jersey, Virgínia e Filadélfia, a demanda e importação de rum da ilha de Barbados, grande produtora de açúcar nos domínios do Império britânico, tendeu a ser superior ao deste próprio produto. Portos da Grã-Bretanha, como os de Londres, Bristol, Liverpool, Lancaster e Falmouth, também importavam rum de cana e o reexportavam para a Irlanda no final do século XVIII ${ }^{24}$.

A produçáo da cana e a indústria do açúcar e da aguardente fizeram parte da história da capitania de São Vicente e depois São Paulo desde o século XVI, quando Martim Afonso de Souza instalou o primeiro engenho da América portuguesa na vila de São Vicente. Mas somente no governo do Morgado de Mateus o açúcar produzido na capitania atingiu o status de produto com demanda no mercado internacional ${ }^{25}$.

Alguns autores, embora não desconsiderem a capacidade da capitania de produção e abastecimento do mercado interno, enfatizaram sua integração ao Reino, na segunda metade do século XVIII, através da produção e exportação da cana-de-açúcar proveniente de certas áreas litorâneas e serra acima ${ }^{26}$.

Dois momentos são considerados decisivos neste processo, como o do governo do Morgado de Mateus, a partir de 1765 , estendendo-se até 1775 , quando ocorreram seus primeiros esforços no sentido de reorganização da economia agrário-mercantil da capitania em direção marítima, tentando promover integração atlântica desse espaço, até então de tradição sertanista e interiorizadora, ao Império português.

Outra conjuntura importante teria sido a do governo de Antonio Manuel de Mello Castro e Mendonça, que desde 1802 representou a consolidação da produção do açúcar e de seu caráter de economia exportadora, que seria posteriormente continuado, a partir da segunda metade do século XIX, com o café.

Recentemente, foi usada a expressão "uma capitania de novos tempos" para refletir sobre esta passagem da capitania de São Paulo da condição de uma região de "vida de fronteira e incursão por interiores e cerrados em busca de metais e pedras preciosas" para uma integraçáo ao Império português, pelo menos até 1808, pela via da agroexportação do açúcar ${ }^{27}$.

\footnotetext{
${ }^{22}$ Registro da proposta que foi apresentada em câmara. Arquivo Histórico Municipal de São Paulo. Atas da Câmara, v. 15, 1768. p. 326-335 e 339-340.

${ }^{23}$ PIJNING, Ernst. A new interpretation of contraband trade. Hispanic American Historical Review, Durhan, v. 81, p. 733738, 2001; _. Contrabando na legislação portuguesa durante o período colonial. In: REUNIÃO DA SOCIEDADE BRASILEIRA DE PESQUISA HISTÓRICA, XIV, 1994, Salvador. Anais... p. 85-88.

${ }^{24}$ FRERE, George. A short history of Barbados from its discovery and settlement to the end of year 1767. Londres: J. Dodsley in Pale-Mal, 1768. p. 14.

${ }^{25}$ PETRONE, Maria Theresa Schorer, A lavoura canavieira em São Paulo, op. cit. p. 12.

${ }^{26}$ Ibidem.

${ }^{27}$ FERLINI, Vera Lúcia do Amaral. Uma capitania de novos tempos: economia, sociedade e política na São Paulo restaurada (1765-1822). Anais do Museu Paulista. Sáo Paulo, v. 17, n. 2, p. 237-250, jul./dez. 2009.
} 
Esse viés é endossado por pesquisas que consideram que o volume de produção do açúcar nos engenhos paulistas e a exportação para o mercado de além-mar cresceram a ponto de estimular a passagem da lógica de abastecimento interno para outra, mercantil e exportadora, da economia paulista ${ }^{28}$. José Jobson Arruda também defende a integração da economia da capitania ao Império português, mesmo após a abertura dos portos, pela via da agroexportação do açúcar pelo porto de Santos, entre 1796 e $1811^{29}$.

Embora fundamentando-se em dados de origem não informada, Sérgio Buarque de Holanda, no texto São Paulo, publicado em 1964, lançou algumas ideias seminais que encontraram eco na historiografia renovada atual sobre a cidade e capitania de São Paulo e que derrubam a perspectiva interpretativa que enfatiza o caráter agroexportador do açúcar da regiáo.

Nesse texto ele desenvolveu um raciocínio que mostra o movimento de forças expansivas e de retração da economia de São Paulo. Ou seja, entre o final do século XVIII e o início do XIX, o movimento da economia da capitania não foi de evolução progressiva da agroexportação, mas de retração desse setor e de expansão mais segura do abastecimento interno e do comércio de cabotagem.

A tabela seguinte, apresentada pelo próprio autor, indica esse movimento através do porto de Santos. Originalmente, essa tabela contém uma coluna com o total de produtos exportados e outra coluna com o total da exportação exclusivamente do açúcar.

Através de uma operação matemática simples de subtração do volume total de exportação do açúcar do total de exportação do porto chega-se a um número correspondente ao que pode ser chamado de "valor total da exportação de outros gêneros". A tabela mostra que, até 1802, o volume de exportação do açúcar cresceu, houve ligeira estabilização até 1804, retorno do crescimento e declínio a partir de 1806.

No que diz respeito ao "valor total das exportaçôes de outros gêneros", considerando tanto a exportação marítima quanto costeira, pois a expressão exportação é usada nos dois sentidos na documentação, o movimento foi exclusivamente progressivo, o que permite concluir que o papel da capitania de abastecedora do mercado do continente é bastante relevante e esse movimento teve tendência progressiva e mais estável, ao contrário da agroexportação do açúcar, que decresceu a partir de 1806.

Valentim Alexandre ${ }^{30}$ já havia demonstrado a tendência de retração do açúcar no conjunto das importaçóes do Reino e através das balanças de comércio, a partir desse período.

Tabela 1

Movimento das exportaçóes no porto de Santos entre 1801-1807

\begin{tabular}{|c|c|c|c|}
\hline Anos & Exportaçáo total & $\begin{array}{c}\text { Exportaçáo do } \\
\text { açúcar }\end{array}$ & $\begin{array}{c}\text { Valor total das exporta- } \\
\text { çóes de outros gêneros }\end{array}$ \\
\hline 1801 & $21: 235 \$ 100$ & $19: 141 \$ 200$ & $2: 093 \$ 900$ \\
\hline 1802 & $66: 015 \$ 000$ & $60: 015 \$ 500$ & $5: 999 \$ 500$ \\
\hline 1803 & $76: 282 \$ 640$ & $60: 171 \$ 400$ & $16: 111 \$ 240$ \\
\hline 1804 & $194: 041 \$ 140$ & $141: 944 \$ 480$ & $52: 096 \$ 960$ \\
\hline 1805 & $273: 930 \$ 540$ & $196: 254 \$ 200$ & $77: 676 \$ 340$ \\
\hline 1806 & $195: 460 \$ 140$ & $103: 227 \$ 200$ & $92: 232 \$ 940$ \\
\hline 1807 & $229: 020 \$ 060$ & $86: 732 \$ 900$ & $142: 287 \$ 160$ \\
\hline
\end{tabular}

Fonte: HOLANDA, Sérgio B. de. São Paulo. In:____ (Dir.). História geral da civilização brasileira.

6. ed. Rio de Janeiro: Bertrand Brasil, 1995. Tomo 2, v. II, p. 419.

\footnotetext{
${ }^{28}$ MONT SERRATH, Pablo Oller. Dilemas e conflitos na São Paulo restaurada: formação e consolidação da agricultura exportadora (1765-1802). Dissertação (Mestrado em História Econômica) — Programa de Pós-graduação em História Econômica, Universidade de São Paulo, 2007. p. 229.

${ }^{29}$ Ibidem, p. 229 e ARRUDA, José Jobson. O Brasil no comércio colonial. São Paulo: Ática, 1980.

${ }^{30}$ ALEXANDRE, Valentim. Os sentidos do Império: questão nacional e questão colonial na crise do Antigo Regime português. Lisboa: Edições Afrontamento, 1993.
} 
Diante desta constatação, pode-se considerar a importância que outros gêneros não tradicionais na pauta de exportaçóes podem ter adquirido no circuito mercantil do continente e internacional.

\section{A aguardente: um derivado da cana-de-açúcar abastecendo o mercado interno}

A aguardente como um derivado da cana, assim como eram o melado e a rapadura, se encaixa no conjunto dos "outros gêneros" apresentados na tabela 1. Sistematizando os dados dos mapas de importação e exportação do porto de Santos entre 1810 e 1821, verifica-se que existiu através desse porto uma demanda tanto interna como externa por esse produto.

O porto da cidade do Rio de Janeiro não foi um captador principal da aguardente na costa sudeste-sul, embora o produto tenha tido uma importante funçáo de troca no tráfico negreiro, um dos principais circuitos mercantis dirigidos pelos negociantes desta praça. A aguardente negociada pelo Rio de Janeiro vinha da própria região e do que pode ser chamado circuito costeiro do norte (Bahia e Recife), como já foi indicado pela historiografia.

$\mathrm{Na}$ costa sudeste-sul, o Rio Grande foi um polarizador da importação de aguardente de Santos, tendo comprado 261 pipas entre 1810 e 1821, como pode ser verificado na tabela 2 . O Rio de Janeiro importou apenas oitenta no mesmo período. O Rio Grande, por sua vez, não exportou aguardente para o Rio de Janeiro, porque tanto Helen Osório como Maximiliano Max Meinz ${ }^{31}$ mostraram que o forte das exportaçóes do Rio Grande para essa praça foram o charque, o couro e o trigo.

A aguardente da capitania de São Paulo tinha, portanto, mais um caráter de abastecimento do mercado do continente, especialmente da parte sul, e não participava do circuito mercantil atlântico Rio de Janeiro-Luanda.

Seguido do Rio Grande, viria o que pode ser chamado complexo do rio da Prata e, desde a abertura dos portos, tanto Buenos Aires como Montevidéu juntos tornaram-se grandes consumidores de produtos coloniais oriundos do porto de Santos. Esse complexo consumiu no período 218 pipas, como pode ser visto na tabela seguinte. Essa mercadoria pode ter sido aproveitada no comércio de escravos dirigido por esses dois portos platinos no período ${ }^{32}$.

Nesse caso e em torno da aguardente pode-se pensar em dois circuitos mercantis estabelecidos a partir da costa sudeste: um atlântico sul, que movimentava o comércio negreiro via Rio de Janeiro, e outro continental, que abastecia o mercado interno dos domínios da América portuguesa e as províncias platinas, via Santos.

Os portos portugueses consumiram maior número de pipas de aguardente, o que concorda com a tese de Alexandre Valentim de tendência de diversificação da demanda da economia portuguesa desde 1806. Segundo esse autor, o açúcar conservava, nesse período, níveis altos de volume de importação, mas decrescentes em relação a outros gêneros não considerados de exportação, como a aguardente, um subproduto da cana, produto não tradicional de exportação e de baixo valor de produção.

\footnotetext{
${ }^{31}$ OSÓRIO, Helen. O Império português, op. cit. e MEINZ, Maximiliano M. Entre dois Impérios: formação do Rio Grande na crise do Antigo Sistema Colonial (1777-1822). Tese (Doutorado em História Econômica) — Programa de PósGraduação em História Econômica, Universidade de São Paulo, São Paulo, 2006.

${ }^{32}$ BORUCKI, Alex. The slave trade to the Río de la Plata, op. cit.
} 
Tabela 2

Portos de destino da aguardente exportada pelo porto de Santos em pipas

\begin{tabular}{|c|c|c|c|c|c|c|c|c|c|c|c|c|c|}
\hline & $\mathbf{1 8 1 0}$ & $\mathbf{1 8 1 1}$ & $\mathbf{1 8 1 2}$ & $\mathbf{1 8 1 3}$ & $\mathbf{1 8 1 4}$ & $\mathbf{1 8 1 5}$ & $\mathbf{1 8 1 6}$ & $\mathbf{1 8 1 7}$ & $\mathbf{1 8 1 8}$ & $\mathbf{1 8 1 9}$ & $\mathbf{1 8 2 0}$ & $\mathbf{1 8 2 1}$ & Total \\
\hline Porto & 20 & & & & 139 & 1 & 2 & & 103 & 13 & 76 & & 354 \\
\hline $\begin{array}{c}\text { Ilha da Boa } \\
\text { Vista }\end{array}$ & 3 & & & & & & & & & & & & \\
\hline Ilha da Madeira & 2 & & & & & & & & & & & & \\
\hline Lisboa & & & & & 13 & & 12 & & 8 & 185 & 95 & & 313 \\
\hline $\begin{array}{c}\text { Portos do Brasil } \\
\text { e Portugal }\end{array}$ & & 82 & & & & & & & & & & & 82 \\
\hline Rio de Janeiro & 1 & & 10 & & 68 & & & & 1 & & & & 80 \\
\hline Pernambuco & & & & & & & & & & & & & \\
\hline Bahia & & & & & & & & & & & & & \\
\hline São Sebastião & & & & & & & & & & & & & \\
\hline Iguape & 7 & & & & 4 & 5 & 8 & & 13 & 11 & 18 & 9 & \\
\hline Paranaguá & & & & & & & & 1,5 & & & & & \\
\hline Sáo Francisco & & & & & & & & & & & & & \\
\hline Laguna & & & & & & & & & & & & & \\
\hline Santa Catarina & & & & & & & & & & & & & \\
\hline Porto Alegre & & & & & & 12 & & & 2 & & & 10 & \\
\hline Rio Grande & 38 & & & & 14 & 52 & 100 & 12 & 9 & 2 & 15 & 19 & 261 \\
\hline Montevidéu & 17 & 5 & & 31 & 15 & & & 4 & & 10 & 20 & & 71 \\
\hline Buenos Aires & 12 & & & 75 & 23 & 26 & 5 & & 6 & & & & 147 \\
\hline Moçambique & & & & & & & & & & & & 8 & \\
\hline Total de pipas & 100 & 87 & 10 & 106 & 276 & 96 & 127 & 17,5 & 147 & 221 & 226 & 46 & \\
\hline
\end{tabular}

Fonte: Arquivo Nacional. Mapas de importação e exportação do porto de Santos entre 1810-1821. Fundo Real Junta de Comércio, cx. 448, pacote 1.

Como mostra a tabela 3, o volume maior de pipas de aguardente exportado para os portos portugueses (Lisboa e Porto) não permite falar em predomínio de uma relação mercantil bipolar porque a tabela mostra que a frequência de embarcaçóes da costa do Brasil no porto de Santos era superior à do reino. Quer dizer, se mais pipas do produto foram enviadas para os portos portugueses é porque a capacidade de carga das embarcaçóes era superior, ou seja, navios, enquanto na costa as embarcaçóes eram de pequeno porte, como sumacas, bergantins e lanchas.

Ao longo de dez anos, apenas 25 navios entraram no porto de Santos, oriundos de Lisboa ou Porto. Tomando como exemplo o ano de 1816, apenas um navio português deu entrada no porto de Santos, enquanto o número de sumacas oriundas de portos da costa do Brasil foi de 55. Logo, o circuito mercantil interno foi mais consistente e contínuo do que o atlântico ou bipolar (Brasil-Reino). 
Tabela 3

Tipos de embarcaçóes que saíram de Santos

\begin{tabular}{|c|c|c|c|c|c|c|c|c|c|c|c|}
\hline & $\mathbf{1 8 0 9}$ & $\mathbf{1 8 1 0}$ & $\mathbf{1 8 1 2}$ & $\mathbf{1 8 1 5}$ & $\mathbf{1 8 1 6}$ & $\mathbf{1 8 1 7}$ & $\mathbf{1 8 1 8}$ & $\mathbf{1 8 1 9}$ & $\mathbf{1 8 2 0}$ & $\mathbf{1 8 2 1}$ & Total \\
\hline Navios & 2 & 4 & 2 & 3 & 1 & 4 & 1 & 2 & 3 & 3 & 25 \\
\hline Corvetas & & 1 & & & & & & & & & 1 \\
\hline Bergantins & & 28 & 18 & 18 & 19 & 19 & 15 & 18 & 14 & 11 & 160 \\
\hline Sumacas & & 38 & 20 & 30 & 55 & 28 & 48 & 64 & 43 & 38 & 364 \\
\hline Lanchas & & 38 & 26 & 49 & 52 & 37 & 29 & 53 & 50 & 74 & 378 \\
\hline
\end{tabular}

Fonte: Arquivo Nacional. Mapas de importação e exportação do porto de Santos entre 1810-1821. Fundo Real Junta de Comércio, cx. 448, pacote 1.

$\mathrm{Na}$ tabela seguinte, de número 4, pode-se também constatar que a praça de Santos importava aguardente dos portos menores da costa da capitania de São Paulo. Ao cruzar os dados da tabela 4 com os da tabela 2, relativos à exportaçáo da aguardente por esse porto, nota-se que a quantidade de pipas importadas era inferior à exportada, com dois momentos apenas em que a importaçáo foi maior que a exportação: 1810 e 1817.

\section{Tabela 4}

\section{Quantidade de aguardente por número de pipas importadas pela vila de Santos na} costa da capitania de Sáo Paulo

\begin{tabular}{|c|c|c|c|c|c|c|c|c|}
\hline & $\mathbf{1 8 1 0}$ & $\mathbf{1 8 1 4}$ & $\mathbf{1 8 1 5}$ & $\mathbf{1 8 1 6}$ & $\mathbf{1 8 1 7}$ & $\mathbf{1 8 1 8}$ & $\mathbf{1 8 1 9}$ & $\mathbf{1 8 2 0}$ \\
\hline Ilha Grande & 5 & & & & & & & \\
\hline Paraty & & & & $2,1 / 2$ & & & & 55 \\
\hline São Sebastião & 106 & 66 & 27 & 46 & 104 & 207 & 104 & \\
\hline Ubatuba & 4 & & 14 & $29,1 / 2$ & 18 & 9 & & 8 \\
\hline Vila Bela & & & 3 & 2 & & & & \\
\hline Total de pipas & 115 & 66 & 44 & 32 & 122 & 216 & 104 & 63 \\
\hline
\end{tabular}

Fonte: Arquivo Nacional. Mapas de importação e exportação do porto de Santos entre 1810-1821. Fundo Real Junta de Comércio, cx. 448, pacote 1.

Se o porto de Santos exportava para os portos do Reino e do continente pipas de aguardente em quantidade superior à captada na costa da capitania, parte do produto provinha de serra acima, da produção das freguesias rurais da cidade de São Paulo, e era desviada do circuito vicinal de abastecimento controlado pela Câmara. Em ofício enviado ao ouvidor da comarca em 1811, os oficiais da Câmara de São Paulo denunciavam o prejuízo causado às finanças municipais por esses extravios ${ }^{33}$.

Há de se considerar, também, que parte da produção era oriunda da própria vila de Santos. Em 1798, a vila produziu sessenta pipas de aguardente e, em 1817, há registros de que a produção atingiu 2:262\$400 34 . Uma pesquisa que mapeasse e conceituasse os engenhos, a produção e a comunidade de lavradores dessa vila seria interessante. Os maços de população são um bom ponto de partida para essa pesquisa.

\footnotetext{
${ }^{33}$ Arquivo Histórico Municipal de São Paulo. Papéis avulsos, v. 9, 1811, p. 285.

${ }^{34}$ Arquivo do Estado de São Paulo. Alfândega — almoxarifado 1722-1822, Santos, C00227, ordem 227, 1798 e Maços de População, Santos, 1817.
} 
Mas, para além da costa, havia uma produção das freguesias rurais, especializada na aguardente de cana, com função de abastecer o mercado local, mas que respondia à demanda costeira do continente e atlântica do Reino. Essa produção integrava a cidade de Sáo Paulo a circuitos mercantis mais distantes, tornando-a parte de um sistema originalmente e apenas antevisto por Caio Prado Jr. e denominado sistema São Paulo-Caminho do Mar-Santos ${ }^{35}$.

\section{Produção e circuito mercantil vicinal da aguardente numa freguesia rural da cidade de São Paulo}

O comércio da aguardente era um dos ramos do comércio de abastecimento local, controlado pelo poder público municipal em muitas vilas da América portuguesa ${ }^{36}$. Em partes do Império hispânico, como em Nueva Galícia, Michoacán e na Nova Espanha, os cabildos também assumiam a responsabilidade sobre os vinhos da terra, entrando muitas vezes em conflitos com os próprios vice-reis ou com as Audiências para defenderem sua produção e comércio ${ }^{37}$.

$\mathrm{Na}$ América portuguesa, ao contrário de certas áreas na América hispânica, não houve proibiçôes em torno da produção e distribuição da aguardente. Mais do que uma bebida popular, esse gênero tinha certas funçôes no comércio colonial e especialmente negreiro.

Mas o produto estava sob rígido controle do poder municipal e seus direitos de venda eram arrematados publicamente, de acordo com a herança do sistema de abastecimento do Antigo Regime. No caso dos vendedores ambulantes, principais agentes do comércio citadino de abastecimento, deveriam tirar uma guia de autorização municipal para comercializar o produto, pagando o tributo régio denominado subsídio literário ${ }^{38}$.

Vários desses vendedores foram condenados pela burocracia municipal por praticarem o negócio da aguardente na cidade sem a guia e, portanto, sem pagar os tributos devidos ${ }^{39}$. Infelizmente, a documentaçáo municipal náo fornece os valores de venda do produto no mercado consumidor local, mas apenas os valores pagos pelos negociantes na arrematação do contrato público.

A tabela seguinte, apesar da irregularidade dos dados, revela que esse ramo do abastecimento local vivia um processo de valorização dos preços da arrematação, o que indica a importância que o setor vinha adquirindo, especialmente a partir da segunda década do século XIX, e com alguns momentos de queda do preço, como em 1810 e 1815.

Isso significa a persistência da lógica de Antigo Regime que mediava o sistema de abastecimento, acompanhando a valorização do produto numa conjuntura de diversificaçáo do mercado consumidor interno e externo.

\footnotetext{
${ }^{35}$ PRADO JR., Caio. Contribuição para a geografia urbana da cidade de São Paulo. In: Evolução política do Brasil e outros estudos. 8. ed. São Paulo: Brasiliense, 1972. p. 111-114.

${ }^{36}$ SOUSA, Avanete Pereira. Poder local, cidade e atividades econômicas (Bahia, século XVIII). Tese (Doutorado em História Econômica) - Programa de Pós-Graduação em História Econômica, Universidade de São Paulo, 2003; JESUS, Nauk Maria. Na trama dos conflitos: administração na fronteira oeste da América portuguesa (1719-1778). Tese (Doutorado em História Social) — Programa de Pós-Graduação em História Social, Universidade Federal Fluminense, 2006; BORREGO, Maria Aparecida de Menezes. A teia mercantil, op. cit.; MOURA, Denise A. Soares de. Comércio de abastecimento e conflitos intercamarários entre Santos e São Paulo (1765-1822). In: DORÉ, Andréa; SANTOS, Antonio César de Almeida (Org.). Temas Setecentistas. Governos e populaçóes no Império português. Curitiba: UFPR; Schila-Fundação Araucária, 2009. p. 517-534.

${ }^{37}$ CHÂVEZ, Claudia Paulina Machuca. Cabildo, negociación y vino de cocos, op. cit.

${ }^{38}$ Esse tributo, que correspondia a $10 \%$ do valor da aguardente, era repassado para a educação na colônia.

${ }^{39}$ Arquivo Histórico Municipal de São Paulo. Atas da Câmara, v. 18, atas de 18, 20 e 23 de abril de 1785, p. $200-203$.
} 
Tabela 5

Valores da arremataçáo do contrato da aguardente

\begin{tabular}{|c|c|}
\hline Ano & Valor \\
\hline 1766 & $32 \$ 000$ \\
\hline 1766 & $52 \$ 000$ \\
\hline 1767 & $52 \$ 100$ \\
\hline 1769 & $52 \$ 500$ \\
\hline 1772 & $60 \$ 200$ \\
\hline 1773 & $51 \$ 200$ \\
\hline 1774 & $44 \$ 100$ \\
\hline 1792 & $64 \$ 500$ \\
\hline 1801 & \\
\hline 1804 & $275 \$ 000$ \\
\hline 1805 & $371 \$ 000$ \\
\hline 1808 & $300 \$ 000$ \\
\hline 1809 & $342 \$ 100$ \\
\hline 1810 & $320 \$ 000$ \\
\hline 1812 & $470 \$ 500$ \\
\hline 1814 & $660 \$ 500$ \\
\hline 1815 & $280 \$ 500$ \\
\hline 1821 & $1: 110 \$ 184$ \\
\hline 1822 & $1: 138 \$ 794$ \\
\hline
\end{tabular}

Fonte: Arquivo Histórico Municipal de São Paulo.

Atas da Câmara e Papéis avulsos, 1765-1822.

Náo foi possível identificar os nomes dos arrematadores do contrato público da aguardente na documentação camarária das duas primeiras décadas do século XIX, justamente na fase de aumento dos preços das arremataçóes. Seria interessante uma investigação que pudesse chegar aos tipos de negociantes que persistiram na lógica de arrematação pública dos contratos de venda da aguardente.

Em certa medida, é possível traçar o perfil dos arrematadores da segunda metade do século XVIII. Seguindo suas pistas nos Maços de População da Capital, conforme a tabela 6, percebe-se que foram indivíduos envolvidos no comércio de abastecimento da cidade, havendo, inclusive, um caixeiro. Apenas três envergaram patente militar. Apenas um arrematador, José Mendes da Costa, foi um negociante que atuava no mercado de longa distância e pode ser considerado um membro do diversificado quadro da elite mercantil local, possuindo, inclusive, a patente de coronel.

Dos quinze arrematadores identificados, todos eram negociantes e nenhum era produtor rural, o que significa que não controlavam a produção do gênero que comercializavam. Havia, portanto, uma clara separação entre os produtores da aguardente e os que a comercializavam, o que destoa de certas áreas na América hispânica, na qual produtores de um gênero também o revendiam ${ }^{40}$. Os negociantes-arrematadores da aguardente residiam no rossio da cidade.

${ }^{40}$ DUPUY, Andrea Lidia. O estanco nas cidades do México e de Buenos Aires: crise e ruptura em meados do século XVIII. Um estudo comparativo. Topoi, Rio de Janeiro, v. 11, n. 21, p. 37-50, jul./dez. 2010. 
Tabela 6

Perfil dos arrematadores do contrato da aguardente da cidade de Sáo Paulo

\begin{tabular}{|c|c|c|c|c|c|c|}
\hline Ano & Contratador & Atividade & Patente & Patrimônio & Residência & Cargo público \\
\hline 1766 & \begin{tabular}{|c|} 
João \\
Fernandes \\
de Oliveira \\
\end{tabular} & Caixeiro & & $* * *$ & & \\
\hline 1766 & $\begin{array}{l}\text { Joaquim } \\
\text { José de } \\
\text { Almeida }\end{array}$ & $\begin{array}{l}\text { Caixeiro, arrematou } \\
\text { estanco de Santo } \\
\text { Amaro em } 1773 .\end{array}$ & $\begin{array}{l}\text { Alferes de } \\
\text { auxiliar } \\
\mathrm{da} \\
\text { cavalaria }\end{array}$ & $* * *$ & Rua Direita & $\begin{array}{c}\text { Procurador em } \\
1771,1772 \text { e } \\
1775 \text { e almotacé } \\
\text { em 1769, 1770, } \\
1782,1785, \\
1791,1793 \text { e } \\
1797 \\
\end{array}$ \\
\hline 1767 & $\begin{array}{c}\text { Luís Pereira } \\
\text { Macedo }\end{array}$ & $\begin{array}{l}\text { Arrematou estanco } \\
\text { de Cotia em } 1771 \text { e } \\
\text { foi fiador de João da } \\
\text { Silva Machado no } \\
\text { contrato de aferição } \\
\text { de pesos e medidas } \\
\text { em } 1776 .\end{array}$ & & $600 \$ 000$ & $\begin{array}{c}\text { Rua de S. } \\
\text { Bento e } \\
\text { Anhangabaú }\end{array}$ & $* * *$ \\
\hline 1769 & $\begin{array}{c}\text { Luís Pereira } \\
\text { Macedo }\end{array}$ & $* * *$ & & $600 \$ 000$ & Idem & $* * *$ \\
\hline 1771 & $\begin{array}{c}\text { José } \\
\text { Antonio da } \\
\text { Silva }\end{array}$ & $\begin{array}{l}\text { Mercador, foi apenas } \\
\text { fiador do estanqueiro } \\
\text { de Juquery em } 1771 \text {, } \\
1774 \text { e } 1775 \text {. } \\
\end{array}$ & \begin{tabular}{|c|} 
Capitão \\
do bairro \\
de Santa \\
Anna \\
\end{tabular} & $\begin{array}{c}500 \$ 000 \text { e } \\
12 \text { escravos } \\
\text { em } 1782\end{array}$ & Rua Direita & $\begin{array}{l}\text { Almotacé em } \\
1765 \text { e juiz em } \\
1775\end{array}$ \\
\hline 1772 & $\begin{array}{l}\text { Gonçalo } \\
\text { José de } \\
\text { Oliveira }\end{array}$ & & & & & \\
\hline 1773 & $\begin{array}{c}\text { José Mendes } \\
\text { da Costa }\end{array}$ & $\begin{array}{c}\text { Mercador, adquiriu } \\
\text { farinha em Paranaguá } \\
\text { para enviar para PE } \\
\text { em 1794, contrato de } \\
\text { aferiçáo dos pesos em } \\
1771 . \\
\end{array}$ & $\begin{array}{l}\text { Alferes de } \\
\text { auxiliar } \\
\text { da cava- } \\
\text { laria }\end{array}$ & $* * *$ & $\begin{array}{c}\text { Rua que } \\
\text { principia } \\
\text { da Lapa e } \\
\text { segue até a } \\
\text { Misericórdia }\end{array}$ & $\begin{array}{c}\text { Procurador em } \\
1776 \text { e juiz em } \\
1783 \text { e } 1791\end{array}$ \\
\hline 1774 & $\begin{array}{c}\text { Antonio } \\
\text { Garcia da } \\
\text { Silva } \\
\end{array}$ & $\begin{array}{l}\text { Contratou casinhas } \\
\text { em } 1774 .\end{array}$ & & $* * *$ & Rua Direita & $* * *$ \\
\hline 1775 & $\begin{array}{c}\text { Antonio } \\
\text { Garcia }\end{array}$ & Idem & & & & \\
\hline 1780 & $\begin{array}{c}\text { João } \\
\text { Soares de } \\
\text { Figueiredo } \\
\end{array}$ & & & & & \\
\hline
\end{tabular}




\begin{tabular}{|c|c|c|c|c|c|c|}
\hline Ano & Contratador & Atividade & Patente & Patrimônio & Residência & Cargo público \\
\hline 1788 & $\begin{array}{c}\text { Antonio } \\
\text { Pinto da } \\
\text { Silva }\end{array}$ & $\begin{array}{c}\text { Arrematador de } \\
\text { contratos públicos } \\
\text { da carne (1770-72) e } \\
\text { casinhas (1775-85) }\end{array}$ & & & & \\
\hline 1789 & $\begin{array}{c}\text { Antonio } \\
\text { Pinto da } \\
\text { Silva }\end{array}$ & Idem & & & & \\
\hline 1790 & $\begin{array}{c}\text { Antonio } \\
\text { Pinto da } \\
\text { Silva }\end{array}$ & Idem & & & & \\
\hline 1791 & $\begin{array}{c}\text { Antonio } \\
\text { Pinto da } \\
\text { Silva }\end{array}$ & Idem & & & & \\
\hline 1792 & $\begin{array}{c}\text { Francisco } \\
\text { de Paula } \\
\text { Ribeiro }\end{array}$ & Idem & & & & \\
\hline
\end{tabular}

Fonte: Arquivo do Estado de São Paulo. Atas da Câmara, Papéis avulsos e Maços de população. Disponível em: $<$ www.arquivoestado.com.br $>$.

Se o ramo público da aguardente, na segunda metade do século XVIII, era de baixo valor de arremate e absorvia negociantes já envolvidos no abastecimento local, o fiador, um importante agente do sistema de contratos do Antigo Regime, era dispensável? A própria inserção no sistema de abastecimento local, baseado numa lógica contratual de Antigo Regime, que obrigava o arrematador a assumir publicamente a obrigação de não deixar faltar certos gêneros no mercado, o tornava pessoa confiável a ponto de não necessitar de um fiador. Nesse caso, diferente do comércio de longa distância, o comprometimento com o comércio de abastecimento local já era algo que, em si, parece dar credibilidade ao negociante.

Se os contratos públicos de direito de venda de um produto eram herdeiros do sistema de abastecimento do Antigo Regime, seria adequado considerar que a ausência do fiador estava relacionada ao baixo valor da arrematação do contrato da aguardente? Como boa parte dos arrematadores já tinha um histórico de envolvimento nos contratos do açougue ou estancos dos distritos da cidade, o mais ajustado seria considerar a capacidade de o sistema imprimir credibilidade pelo simples fato de se envolver nele. Dos quinze arrematadores identificados no contrato da aguardente, apenas sete apresentaram fiador, conforme verificado na tabela 7 .

Tabela 7

Perfil dos fiadores dos arrematadores do contrato da aguardente da cidade de Sáo Paulo

\begin{tabular}{|c|c|c|c|c|c|c|c|}
\hline Ano & Fiador & Atividade & Patente & Patrimônio & $\begin{array}{c}\text { Cargo } \\
\text { público }\end{array}$ & $\begin{array}{c}\text { Valor da } \\
\text { arremataçáo }\end{array}$ & Residência \\
\hline 1766 & $\begin{array}{c}\text { Domingos } \\
\text { Francisco de } \\
\text { Andrade }\end{array}$ & $\begin{array}{c}\text { Mercador, vive de } \\
\text { seu negócio, genro } \\
\text { do negociante } \\
\text { Manuel Joaquim } \\
\text { de Toledo. }\end{array}$ & $400 \$ 000$ & $\begin{array}{c}\text { Foi juiz } \\
\text { em } 1777 \\
\text { e } 1778 .\end{array}$ & $32 \$ 000$ & \\
\hline
\end{tabular}




\begin{tabular}{|c|c|c|c|c|c|c|c|}
\hline Ano & Fiador & Atividade & Patente & Patrimônio & $\begin{array}{c}\text { Cargo } \\
\text { público }\end{array}$ & \begin{tabular}{|c|} 
Valor da \\
arremataçáo \\
\end{tabular} & Residência \\
\hline 1766 & $\begin{array}{c}\text { José Antonio } \\
\text { Rodrigues }\end{array}$ & Mercador & & $60 \$ 00$ & & $52 \$ 000$ & \begin{tabular}{|c|} 
Na rua \\
Direita, a \\
mesma do \\
contratador, \\
mas em \\
fogos \\
separados. \\
\end{tabular} \\
\hline 1767 & $\begin{array}{c}\text { João da Silva } \\
\text { Machado }\end{array}$ & $\begin{array}{l}\text { Ajudante do } \\
\text { regimento, } \\
\text { caldeireiro. }\end{array}$ & & $\begin{array}{l}100 \$ 000 \\
300 \$ 000\end{array}$ & $\begin{array}{c}\text { Escrivão } \\
\text { de } \\
1765-88 .\end{array}$ & $52 \$ 100$ & \\
\hline 1769 & $\begin{array}{c}\text { João da Silva } \\
\text { Machado }\end{array}$ & $\begin{array}{c}\text { Ajudante do } \\
\text { regimento, } \\
\text { caldeireiro, } \\
\text { foi fiador do } \\
\text { estanqueiro de } \\
\text { Cotia em 1768, } \\
\text { arrematou o } \\
\text { estanco de Cotia } \\
\text { em } 1769 \text { e o de } \\
\text { Conceição de } \\
\text { Guarulhos em } \\
1770 \text {, foi fiador } \\
\text { do contratador do } \\
\text { estanco da Borda } \\
\text { do Campo em } \\
1773 \text { e arrematou } \\
\text { contrato de aferiçáo } \\
\text { de pesos e medidas } \\
\text { de } 1767-73 \text {. } \\
\end{array}$ & & $\begin{array}{l}100 \$ 000 \\
300 \$ 000\end{array}$ & $\begin{array}{c}\text { Escrivão } \\
\text { de } \\
1765-88 .\end{array}$ & $52 \$ 500$ & \\
\hline 1771 & $\begin{array}{c}\text { Manoel } \\
\text { José da } \\
\text { Encarnação }\end{array}$ & $\begin{array}{c}\text { Vendeiro e trata de } \\
\text { outros negócios, } \\
\text { foi fiador do } \\
\text { contratador do } \\
\text { açougue em } 1774 \text { e } \\
\text { do estanqueiro de } \\
\text { Cotia em } 1781 . \\
\end{array}$ & & *** & *** & & \begin{tabular}{|c|} 
Mora no \\
fogo de \\
uma viúva \\
numa \\
travessa \\
que segue \\
para a Sé.
\end{tabular} \\
\hline 1773 & $\begin{array}{c}\text { João da Silva } \\
\text { Machado }\end{array}$ & Caldeireiro & $\begin{array}{c}\text { Auxiliar } \\
\text { de } \\
\text { cavalaria }\end{array}$ & $\begin{array}{l}100 \$ 000 \\
300 \$ 000\end{array}$ & $\begin{array}{c}\text { Escrivão } \\
\text { de } \\
1765-88 .\end{array}$ & $51 \$ 200$ & \\
\hline 1774 & $\begin{array}{c}\text { José Velloso } \\
\text { Carmo }\end{array}$ & & & & & $44 \$ 100$ & \\
\hline
\end{tabular}

Fonte: Arquivo do Estado de São Paulo. Atas da Câmara, Papéis avulsos e Maços de população. Disponível em: $<$ www.arquivoestado.com.br $>$. 
Esses fiadores, por sua vez, não eram homens que envergavam um dos principais símbolos daqueles que pertenciam ao complexo quadro das elites locais, ou seja, a patente militar elevada. Mesmo os negociantes-arrematadores não eram senhores de altas patentes, o que sugere ainda mais que o envolvimento com o abastecimento local já era um mecanismo de distinção social para aqueles que não tinham os qualificativos necessários para alcançar uma patente alta ou média nas ordenanças.

Curioso é que três fiadores eram escrivães e, nesse caso, a escrita era um distinguidor social, além da confiança que se depositava - ou pelo menos se deveria depositar — sobre aqueles que tinham o poder da leitura e da escrita. Fiadores com ofício de escrivão também poderiam ser bons auxiliares na contabilidade dos negócios.

Outra questão a ser levada em consideração é a da possibilidade dos negociantes-arrematadores se inserirem no setor público de abastecimento objetivando mais ou também acesso privilegiado a mercadorias, como a aguardente, um produto com altas demandas conjunturais.

Com esse acesso privilegiado poder-se-ia revender o produto não no mercado consumidor local, mas no mercado costeiro ou marítimo. A documentação das Atas da Câmara e Papéis avulsos insiste em denunciar a ação de atravessadores e o extravio do produto ${ }^{41}$.

Esses arrematadores do contrato da aguardente, em pequena medida, fizeram parte da burocracia municipal, como escrivães, procuradores, almotacés ou juízes, na segunda metade do século XVIII, e nenhum ocupou o degrau primeiro do poder municipal: a vereança. Ou seja, não é possível fazer uma intrínseca associação entre negociante do mercado de abastecimento local e poder público. Dos quinze arrematadores identificados, apenas quatro foram funcionários ou oficiais da Câmara.

No que diz respeito ao mercado costeiro e atlântico, a aguardente tinha preço estável, com demanda certa, o que garantia margem segura de ganho, embora inferior ao de venda do açúcar. Não é possível saber o valor do produto no mercado citadino, mas o que atraía o mercado da costa parece ter sido a demanda segura.

$\mathrm{Na}$ exportação, a aguardente era vendida em pipas, equivalendo cada uma a trezentas canadas. No mercado consumidor das cidades e vilas a venda era feita por canadas, o que equivalia a 1,4 litro cada uma. Os preços das pipas e das canadas no litoral mantiveram certa estabilidade, como pode ser observado pela tabela 8 .

Tabela 8

Valor individual de venda das pipas e canadas de aguardente

\begin{tabular}{|c|c|c|}
\hline Ano & Pipa & Canada \\
\hline 1810 & $48 \$ 000$ & $\$ 160$ \\
\hline 1811 & $60 \$ 000$ & $\$ 200$ \\
\hline 1812 & $60 \$ 000$ & $\$ 200$ \\
\hline 1813 & $50 \$ 000$ & $\$ 166$ \\
\hline 1814 & $60 \$ 000$ & $\$ 200$ \\
\hline 1815 & $50 \$ 000$ & $\$ 166$ \\
\hline 1816 & $50 \$ 000$ & $\$ 166$ \\
\hline 1817 & $50 \$ 000$ & $\$ 166$ \\
\hline
\end{tabular}

${ }^{41}$ Arquivo Histórico Municipal de São Paulo. Papéis avulsos, v. 9, p. 285, 1811. 


\begin{tabular}{|c|c|c|}
\hline Ano & Pipa & Canada \\
\hline 1818 & $50 \$ 000$ & $\$ 166$ \\
\hline 1819 & $50 \$ 000$ & $\$ 166$ \\
\hline 1820 & $50 \$ 000$ & $\$ 166$ \\
\hline 1821 & $50 \$ 000$ & $\$ 166$ \\
\hline
\end{tabular}

Fonte: Arquivo Nacional. Mapas de importação e exportação do período 1810-21.

Fundo Real Junta de Comércio, cx. 448, pacote 1.

A constatação da existência de circulação da aguardente na cidade de São Paulo, do interesse de autoridades públicas municipais por esse circuito e da concorrência que enfrentava com a demanda do circuito mercantil terrestre do caminho do mar leva à questão do local da produção dessa aguardente na capitania.

\section{Senhores de engenho e produtores de aguardente em engenho alheio}

Dada a demanda comprovadamente existente para a aguardente tanto no mercado regional como externo, sua fabricação merece ser discutida. Geralmente, contudo, esse assunto é apenas mencionado ou brevemente tratado em trabalhos mais centrados no tema da economia agroexportadora da cana-de-açúcar. Em pesquisa recente sobre o poder municipal e o comércio na cidade de São Paulo, a fabricação da aguardente foi identificada em inventários de época ${ }^{42}$.

Na capitania de São Paulo e especialmente no litoral e na vila de Santos existem notícias de que no século XVIII havia dezoito engenhos que produziam cana exclusivamente para a produção de aguardente. Em Cananeia havia três destilarias de aguardente que produziam 121/2 canadas do produto. No fim do século XVIII, quase toda a produção da cana em Paranaguá era destinada à fabricação da aguardente.

As vilas litorâneas do norte da capitania foram promissoras na produção desse gênero. São Sebastião, por exemplo, em 1797, produzia 131 pipas de aguardente, em 1798, passou para 229 canadas e, em 1799, para 239. Em 1797, havia na ilha de São Sebastião dezesseis destilarias de aguardente. Em Ubatuba, em 1798, havia seis engenhos que produziam 21 pipas de aguardente e, em 1799, esse número se elevou para sete engenhos, com produção de onze pipas do produto.

A aguardente também era fabricada na área do caminho para o Rio de Janeiro, como Mogi das Cruzes, Jacareí, São José, Pindamonhangaba, Guaratinguetá, Lorena e Cunha. O tradicional quadrilátero do açúcar também foi um produtor da aguardente, destacando-se Campinas, que em 1799 tinha 93 engenhos com destilação e 93 destilarias que produziam 7.399 canadas de aguardente. Em Jundiaí, em 1818, havia quarenta engenhos de cana e aguardente. Em direção ao sul destaca-se Sorocaba, que em 1790 tinha onze senhores de engenho que produziam 345 canadas de aguardente ${ }^{43}$.

Algumas regiōes se especializaram na produção de aguardente de cana, como Campos, Parati e Ilha Grande no Rio de Janeiro, e Caio Prado Jr. fez referência a essas especializaçôes regionais na economia agrária da América portuguesa. Na cidade de Salvador, em 1757, existiam 39 destilarias, além de 32 no

\footnotetext{
${ }^{42}$ Para a primeira visão: PETRONE, Maria Theresa Schorer. A lavoura canavieira em São Paulo, op. cit.; SCHWARTZ, Stuart B. Segredos internos, op. cit.; FERLINI, Vera. Uma capitania de novos tempos, op. cit. Uma pesquisa recente: BORREGO, Maria Aparecida. A teia mercantil, op. cit.

${ }^{43}$ PETRONE, Maria Theresa Schorer. A lavoura canavieira em São Paulo, op. cit. p. 26-27, 31, 40, 43, 51.
} 
Recôncavo, produzindo aguardente de cana para consumo local; em momentos de baixa do preço do açúcar no mercado internacional, os produtores optaram em investir na produção da cachaça ${ }^{44}$.

As freguesias rurais de cidades, como Salvador, São Paulo e Rio de Janeiro, se especializaram na produção de alimentos e alguns de seus gêneros adquiriram status de exportaçáo, como foi o caso da aguardente. Os Maços de população da cidade de São Paulo no ano de 1802 mostram que havia unidades produtoras de aguardente nas freguesias da cidade, como Ó e Santana, as duas principais. Na Penha residiam em grande medida os chamados roceiros, com uma produção diversificada de alimentos para subsistência.

As unidades produtivas das freguesias rurais são um bom objeto de pesquisa e os dados dos componentes de fogos (domicílios) fornecidos pelos Maços de populaçáo, como nomes dos moradores, estado civil, naturalidade de seus chefes, outras atividades, patente, quantidade de escravos, filhos, agregados, são um primeiro passo para a pesquisa sobre o assunto.

Uma questão absolutamente em aberto é a da extensão dessas unidades produtoras de aguardente instaladas nas freguesias rurais da cidade. Uma pesquisa recente sobre a concessão de terras na vila de São Paulo considerou que as datas de terra afastadas do núcleo urbano tinham dimensão espacial maior do que aquelas situadas no núcleo urbano propriamente dito. A conclusão, contudo, ainda é muito imprecisa ${ }^{45}$.

Certamente que precisões numéricas não fazem parte das concepções das sociedades rurais de Antigo Regime. Contudo, outros parâmetros podem ser estabelecidos, como a quantidade de residentes, especialmente cativos, num mesmo domicílio, a quantidade de outros domicílios que dão a medida de um terreno ou a quantidade de referências topográficas ou fluviais.

Se localizados os inventários dos chefes dos domicílios, eles certamente trazem essas informaçôes na descrição da extensão dos terrenos de engenhos e sítios, o que levaria a uma visão mais consistente do tamanho dessas unidades produtivas de aguardente nas freguesias rurais.

Um estudo sobre essas unidades produtivas poderia se somar à produção historiográfica recente que vem relativizando imagens mais compactas sobre a economia e a sociedade das cidades nos impérios ibéricos. Juan Carlos Garavaglia, Samuel Amaral e José Maria Ghio fizeram isso para a região de Buenos Aires. Recorrendo à lista de dízimos e aos inventários, puderam comprovar que a região de Buenos Aires não se limitava à criação de gado, mas também era produtora de alimentos ${ }^{46}$.

A cidade de São Paulo, portanto, não foi apenas um entreposto comercial, mas suas freguesias rurais tiveram produçáo de alimentos fornecidos para o mercado regional de abastecimento e a produção da aguardente, que descia a serra e também era redistribuída pela costa, para o Rio Grande, Buenos Aires, Montevidéu, Rio de Janeiro e portos portugueses.

Pirajuçara e Freguesia do Ó, na direção norte da cidade, eram áreas de "senhores de engenho" ou de "agricultores que fizeram aguardente em engenho alheio", como informa a documentação dos Maços de população. Mas a aguardente que circulava na cidade também vinha de Santana do Parnaíba, Jundiaí, Itu e Mogi Mirim ${ }^{47}$.

No ano de 1802, dos 167 fogos da Freguesia do Ó, 125 eram formados por produtores. Desses, cinquenta eram "senhores de engenho" e treze eram "agricultores que produziam aguardente em engenho

\footnotetext{
${ }^{44}$ SCHWATZ, Stuart. Segredos internos, op. cit. p. 112 e 205; PRADO JR., Caio. Formação do Brasil contemporâneo, op. cit. p. 138 e 142.

${ }^{45}$ RIBEIRO, Fernando V. Aguiar. Poder local e patrimonialismo: a Câmara Municipal e a concessão de terras urbanas na vila de São Paulo (1560-1765). Dissertação (Mestrado em História Econômica) — Programa de Pós-Graduação em História Econômica, Universidade de São Paulo, 2010. p. 121.

${ }^{46}$ AMARAL, Samuel; GHIO, Jose Maria. Diezmos y producción agraria. Buenos Aires, 1750 1800. Revista de Historia Económica, Madri, v. 3, p. 619-647, 1990 e GARAVAGLIA, Juan Carlos. Pastores y labradores de Buenos Aires, op. cit.

${ }^{47}$ Atas da Câmara. Arquivo Histórico Municipal de São Paulo, v. 9, p. 6-11, 1810.
} 
alheio", totalizando 63 fogos dedicados à produção do gênero. Predominaram os senhores de engenho e, dos cinquenta, cinco eram mulheres.

O próprio brigadeiro Antonio José da Franca e Horta, que fora governador de Sáo Paulo entre 1802 e 1811, era um senhor de engenho na Freguesia do Ó. Entre 1816 e 1818, os Maços de população registram que ele possuía 51 e 53 escravos, respectivamente. Sua produçáo de aguardente variou de oitenta a noventa canadas.

Tanto os senhores de engenho como os lavradores produziam cana para fabricar aguardente, tratando-se, portanto, de uma produção citadina especializada. A produção da aguardente de cana era menos dispendiosa e feita em instalaçóes mais simples do que as do beneficiamento do açúcar. Descriçóes no Brasil e nas Antilhas já mostraram a complexidade e os custos de implantação da indústria da cana-de-açúcar ${ }^{48}$.

$\mathrm{Na}$ ilha da Madeira, em período avançado do século XIX, o combate à produção da aguardente em favor da reabilitação da produção do vinho enfrentava a facilidade da produção da aguardente e o imediato mercado consumidor encontrado por esse produto ${ }^{49}$.

Essas características podem ter feito da produção da aguardente uma atividade atraente para as unidades rurais de freguesias das cidades, menos extensas territorialmente e com população pequena de escravos, sendo, portanto, "uma produção mais democrática do que o aristocrático açúcar" 50 .

Outros atrativos também existiam. Na Bahia, o produto era isento da cobrança do dízimo e não era dividido com os lavradores, ficando como uma propriedade do engenho, que o vendia localmente, ou seja, não era um produto de exportação. Os senhores de engenho baianos diziam que a cachaça era seu lucro e o açúcar apenas cobria-lhes as despesas ${ }^{51}$.

A estabilidade dos preços e o mercado consumidor certo, como apontado anteriormente, contribuem para endossar essa observação. Em São Paulo, a situação é semelhante à da Bahia, porque sobre a aguardente incidia apenas a cobrança do subsídio literário, um imposto instituído pelo Alvará Régio de 1772, destinado a pagamentos e reformas na área da instrução pública. Contudo, era um imposto cobrado muito irregularmente, o que garantia margens de ganho para o negociante. $\mathrm{O}$ valor previsto para ser cobrado sobre cada canada de aguardente era de $\$ 140$.

Mas havia muitas variaçóes nessas cobranças. A tendência foi a do valor do subsídio ser $\$ 160$ por canada, mas em um documento da câmara de 1810 existe o registro de cobrança de 0,5 pataca de engenhos de propriedade de mulheres. Dos senhores de engenho os valores variaram de 12,5 patacas até $\$ 231^{52}$.

Os dois tipos de unidades produtivas de aguardente descritas acima, ou seja, as dos senhores de engenho e as dos lavradores em engenho alheio, não se restringiam apenas à produção da aguardente, ou seja, produziam também outros gêneros de subsistência ou negociados no mercado local da cidade, como milho, feijão, farinha de mandioca e algodão. Geralmente esses gêneros aparecem como "gasto com a própria família" e a aguardente sempre como "vendida na cidade".

Do total de 63 unidades produtivas — englobando os dois tipos definidos —, 42 também criavam animais vacuns e cavalares, que também eram, de modo geral, comercializados na cidade. $\mathrm{O}$ comércio da carne, a venda de rezes para o açougue público da cidade, era um importante setor do mercado regional de abastecimento. Por outro lado, o gado vacum ou cavalar fazia parte dos equipamentos de um

\footnotetext{
${ }^{48}$ WURDEMAN, F. Notes on Cuba. Boston: James Munroe and Company, 1844 e Schwartz, Stuart, op. cit.

${ }^{49}$ VALDEZ, Francisco Travassos. Africa Occidental. Notícias e consideraçóes. Lisboa: Imprensa Nacional, tomo 1, p. 58, 1864.

${ }^{50}$ PRADO JR., Caio. Fomaçâo...op. cit., p. 142.

${ }^{51}$ SCHWARTZ, Stuart, op. cit., p. 186.

52 Arquivo Histórico Municipal de São Paulo. Atas da Câmara, v. 9, p. 6-11, 1810.
} 
engenho, pois movimentavam moendas, transportavam a cana ou a lenha e o produto acabado para ser comercializado na cidade.

Nos engenhos, predominaram aqueles que produziram até dez canadas (31 unidades); seguidos dos que produziam entre dez e vinte canadas (nove unidades) e, por último, os que produziam acima de vinte canadas (dez unidades). A conclusão desses números é a de que predominou a pequena produção, mesmo em engenhos, o que pode ser atribuído a diversos fatores como pequena extensáo das propriedades, baixo número de mão de obra, diversificação de suas atividades agrocriatórias.

Os "agricultores que produziram aguardente em engenho alheio" alcançaram níveis produtivos bem mais baixos: onze produziram até dez canadas e apenas dois produziram entre dez e vinte canadas. Uma pesquisa sobre como funcionava essa condição de "agricultor que produz aguardente em engenho alheio" nas freguesias das cidades coloniais seria bem valiosa.

Seria interessante saber como era o pagamento pelo uso do engenho alheio: em porcentagem de cana ou de aguardente? Também seria interessante acompanhar o movimento dos níveis de produção dos engenhos e dos "produtores de aguardente de engenho alheio" ano a ano nos Maços de populaçáo da capital.

Um banco de dados formados com os nomes dos senhores de engenho e com os dos lavradores daria condiçóes para a pesquisa nos registros paroquiais, conforme a metodologia proposta por João Fragoso em texto recente, e levaria à construçáo do tipo de relação que havia entre esses dois segmentos. Ou seja, eles nutriam relaçóes de compadrio? Certamente a relação era hierarquizada, mas como ela se expressava?

Tal tarefa poderia dar condiçôes de comparaçóes com a realidade do Recôncavo da Bahia, investigado por Stuart Schwartz, que identificou essa camada de lavradores tão dependente dos engenhos, mas que também fazia os senhores de engenho serem tão dependentes dela. Os lavradores, no caso da Bahia, faziam parte da elite, tinham status, prestígio e poder. É possível fazer esse mesmo tipo de consideração nas freguesias rurais das cidades?

Quanto à propriedade de escravos. e quantificando apenas os engenhos. constata-se que. de modo geral, eram pequenas unidades escravistas. Ou seja, dos cinquenta engenhos, 39 possuíam escravos, sendo 34 com até dez escravos, quatro com até vinte e apenas um com sessenta escravos.

Comprovadamente, os senhores de engenho e "produtores de aguardente em engenho alheio" eram predominantemente nascidos na cidade ou em partes do centro-sul, como Goiás, Paranaguá ou Minas Gerais. Apenas três eram portugueses: Bispado do Porto, Vizeu e Lamego. Tratava-se, portanto, de uma camada social formada por agentes produtivos nascidos em São Paulo e que não se envolveram em atividade mercantil.

Os negociantes-arrematadores do contrato de venda da aguardente não eram produtores desse gênero. Ou seja, parece ter havido uma distinção entre esses dois grupos. A condição de nascido na América portuguesa certamente facilitava o acesso à terra, concedida em datas pela Câmara Municipal e, portanto, a própria condição de tornar-se um senhor de engenho ou lavrador.

Tendo em vista que a base demográfica pelo menos de uma das freguesias rurais da cidade de São Paulo era comprovadamente formada por indivíduos nascidos na própria cidade, seria possível dizer que sua estrutura fundiária era herdeira das antigas famílias de sertanistas? ${ }^{53}$ Grupos novos, migrantes de outras partes do Império, teriam permanecido no rossio, dedicando-se a atividades mercantis, às arremataçóes de venda da aguardente, diante de uma maior dificuldade para se inserir na estrutura fundiária da cidade?

Se os negociantes se incorporavam nas estruturas de oficiais e funcionários públicos municipais, essa seria uma maneira de se defenderem e se qualificarem perante uma comunidade de potentados residen-

${ }^{53}$ Essa questão está diretamente inspirada em FRAGOSO, João. Efigênia Angola, Francisca Muniz forra parda, op. cit. 
tes nas freguesias rurais, herdeiros de uma ilustre nobreza não só nascida na terra, mas que arriscou sua vida nos sertóes em serviços prestados à Coroa? Para além dos registros paroquiais, a nobiliarquia de Pedro Taques poderia ser um bom caminho para identificar as genealogias desses senhores de engenho e lavradores ${ }^{54}$.

Em pontos da América hispânica, como em algumas vilas da Nova Espanha, a produção das ditas bebidas espirituosas, como o vinho de coco, era uma atividade que empregava a mão de obra dos índios chinos. As haciendas produtoras estavam nas mãos de vecinos espanhóis. O mercado do vinho de coco, em regiôes como Colima, se desenvolveu à revelia das proibiçôes da Coroa hispânica, que temia a concorrência desse produto com o vinho de Castela ${ }^{55}$.

Em freguesias rurais da América portuguesa a produção da aguardente empregava tanto mão de obra cativa como familiar e era controlada pelos nascidos na própria terra. Esse era um tipo de produçáo que tanto favorecia a tributaçáo municipal como beneficiava o tráfico de escravos, um dos mais importantes empreendimentos do Império português praticados por negociantes portugueses residentes nas principais praças mercantis do Brasil, como Rio de Janeiro e Bahia.

Se em partes da Nova Espanha a produção de vinho de coco, conforme mostrou Claudia Chaves, foi, além de um importante produto de um mercado regional, um símbolo de resistência do poder local dos cabildos à pressão régia contrária à produção desse gênero, na América portuguesa a fabricação da aguardente foi uma das peças do seu diversificado comércio costeiro e atlântico. Ao contrário da Coroa espanhola, a Coroa portuguesa não temia concorrências, pois o tráfico atlântico de escravos precisava mais da aguardente produzida nas terras do Brasil do que do vinho produzido em seu continente.

\section{Conclusão}

Inegavelmente, a agroexportação do açúcar levou para o Atlântico a economia até então interiorizadora da capitania de São Paulo, movimentando um de seus principais portos, o de Santos.

Mas o açúcar teve de concorrer com a realidade da consolidação segura da produção e comércio de outros gêneros, como a aguardente, que tanto abastecia o mercado português como o da costa sudeste-sul e das províncias platinas.

Gêneros como esses, dada a expansão da demanda na primeira metade do século XIX, contribuíram para integrar economias e grupos produtores de outras áreas serra acima e em direção ao interior, como a cidade de São Paulo, a outros espaços na parte sul do continente e fora dele. Este texto procurou, através de algumas conclusóes de pesquisa, chamar a atenção e indicar um caminho para mais investigaçóes que possam esclarecer esse aspecto da sociedade colonial de Antigo Regime na América portuguesa.

\footnotetext{
${ }^{54}$ LEME, Pedro Taques de Almeida Paes. Nobiliarquia paulistana, histórica e genealógica. 5. ed. Belo Horizonte: Itatiaia; São Paulo: Edusp, 1980. 3 v.

${ }^{55}$ CHÁVEZ, Claudia Paulina Machuca. Cabildo, negociación y vino de cocos, op. cit.
} 